\title{
Outstanding in his field
}

\section{James Clerk Maxwell's work on the electromagnetic field started a revolution.}

\section{The Man Who Changed \\ Everything: The Life of James Clerk Maxwell \\ by Basil Mahon \\ Wiley: 2003. 254pp. $£ 18.99$, \$27.95}

\section{John Maddox}

James Clerk Maxwell was the most perceptive physicist in the interval between Faraday and Einstein, H. A. Lorentz, Heinrich Hertz and Ludwig Boltzmann and their like notwithstanding. Basil Mahon, the author of this affectionate biography of Maxwell, is an ex-officer in the British Army and a former civil servant, who confesses that at the age of 16 he had "fallen under the spell" of Maxwell. Half a century after the infatuation, the book is evidently a retirement project. But it is none the worse for that.

Mahon tells the tale of Maxwell's childhood economically but well. Maxwell's father had been an unenthusiastic Edinburgh lawyer who married in his late thirties and, with his new wife, embarked on revitalizing a 6-square-kilometre estate that he had inherited in Galloway in southwest Scotland. James was born in 1831 and was educated at home by his mother, Frances, until her death when he was eight (after surgery for cancer without the benefits of anaesthetics). Two aunts in Edinburgh then persuaded the widower that young James should attend a proper school - the Edinburgh Academy.

Maxwell's first scientific paper - an ingenious generalization of the familiar construction of an ellipse by anchoring an inelastic string to two fixed points and letting a pencil constrained by the string trace out a curve - was published while he was still at school, aged 14. That ensured he was noticed in the small-town Edinburgh of 1846.

Father and son were still undecided about James's future, so he signed up for the standard degree course at the University of Edinburgh and immersed himself in science and mathematics. There he published two further papers, one of which - a mathematical framework for the treatment of the distribution of stress and strain in an elastic solid - became, mostly in other hands, one of the monuments of British nineteenthcentury physics.

After three years, his father abandoned his ambition that his son should become a lawyer. James's scientific bent was acknowledged and he was sent off to Cambridge, where he prospered marvellously. He graduated in 1854, at the age of 23 , as 'second wrangler' (he was placed second in the lists of those completing the mathematical Tripos examination) and joint holder of that year's

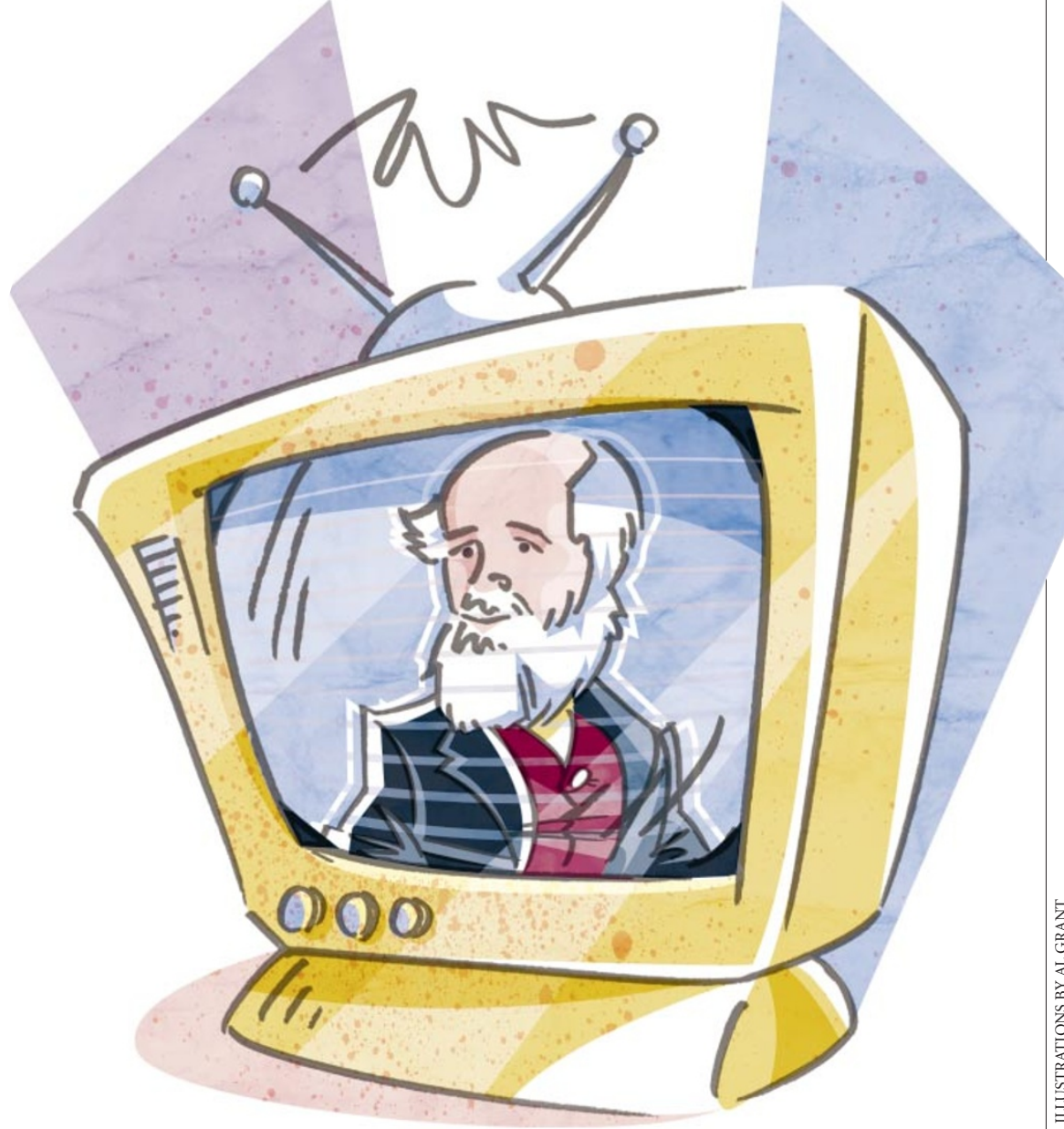

Smith's Prize. An academic career, beginning with a fellowship at Trinity College, Cambridge, was assured. And Maxwell began in fine style, by establishing the three-colour theory of colour vision: the assertion that red, green and blue light in an appropriate mixture will give any colour.

His formal academic appointments were all brief. He was professor of physics at the Marischal College until made redundant by the merger that created the University of Aberdeen; he held the same post at King's College London for five years; and, after a gap of six years, he was professor of experimental physics at Cambridge, where he oversaw the design, construction and commissioning of the Cavendish Laboratory until his untimely death seven years later.

Mahon repeatedly reminds his readers that Maxwell was not a mere theoretician but could devise (and then carry out) telling experiments. There were, for example, spinning tops carrying differently coloured paper on whose colour subjects would be asked to comment. But Maxwell's high point as an experimentalist must surely have been his design of equipment to measure the viscosity of a gas by means of counter-rotating discs in a closed cylindera crucial test of his kinetic theory of gases which was installed and operated in the attic of his London house.

His main body of work was virtually complete within 18 years of his graduation. It consisted of his kinetic theory of gases and his theory of the electromagnetic field, better known as Maxwell's equations. Mahon has also a salutary reminder that Maxwell, as chairman of a committee appointed by the British Association to make sense of electrical units, provided the whole of science with a rational way of choosing units of measurement. How could Maxwell have been so prolific, and in such a short time?

The simple answer is that Maxwell was a genius, but that is a cop-out. What kind of genius was he? First, his penetrating insight into the nature of reality was primarily geometrical. His elegant use in an 1867 paper of 
a simple diagram to relate the velocities of two molecules before and after a collision makes that plain.

Second, he was not a perfectionist. His algebra, for example, was often spattered with simple errors, unworthy of even a second wrangler. And he was not afraid to publish theories that were manifestly incomplete. Thus Maxwell's equations (published in 1872) were preceded by an attempt to put Faraday's lines of force into mathematical language (in 1861) and by a fanciful model (in 1865) in which the whole of space was occupied by tiny cells capable of carrying charge and rotation (whence the magnetic part of the field). Mahon performs the public service of providing an understandable account of the workings of the tiny cells that were supposed to be the basis of the electromagnetic field.

Third, Maxwell kept worrying away at problems (the kinetic theory and electrodynamics) until their solution had the ring of truth - and then he wrote a book on the subject.

Maxwell's equations were famously found to contain the conclusion that electromagnetic waves travel with the speed of light. Maxwell (and his contemporaries) saw what a breathtaking result that was. Sceptical of action at a distance, the cell-like structure with which he had endowed all space was replaced by the doctrine of the lumeniferous ether.

It seems that Maxwell fell in with the fashion of the day, even to the extent of suggesting in a letter to the director of the US Naval Observatory that the expected 'ether drift' (in which the ether is partly carried along by massive objects such as planets) might be measured by accurate timing of the eclipses of Jupiter's moons. The letter came to light only after Maxwell's death in 1879, aged 48 (see Nature 21,314-315; 1880). Had the data been available during Maxwell's life, there is every chance that he would have anticipated the MichelsonMorley experiment, and that he might have seen the need for special relativity two decades before Einstein. He was that kind of man.

Speculation of this kind belongs, of course, to the disreputable school of the history of what might have been. For Mahon, it is enough that Maxwell paved the way for the revolution to come. Maxwell may have been Mahon's hero for the past 40 years, but his book is not hagiography. General readers will glean from it not merely an absorbing account of Maxwell's life but also an explanation of why his work is at the foundation of the modern world.

John Maddox, now Emeritus Editor, was Editor of Nature for the periods 1966-73 and 1980-95.

\section{Harnessing science for Hitler}

\section{Hitler's Scientists: Science, War and the Devil's Pact}

by John Cornwell

Viking: 2003. 544 pp. £20, \$29.95

\section{Kristie Macrakis}

Adolf Hitler's ignorance about science and its utility during the early years of the Third Reich have become part of legends passed down by scientists and administrators for the next generation. The most-often repeated anecdotes involve Hitler's meetings with Max Planck, Nobel prizewinner and science administrator, and Albert Speer, Hitler's armaments minister. According to Planck, when he tried to persuade Hitler that doing away with Jewish scientists might be harmful, Hitler reportedly dismissed the idea saying: "So we'll do without science for a few years." Even during the Second World War, when leaders had begun to see the utility of science for the war effort, Speer related in his postwar memoirs that the concept of the atomic bomb "strained Hitler's intellectual capacity".

The title of this book implies that
Hitler had a stable of scientists who worked under his direction. This was not the case, but many scientists, physicians and engineers who worked in National Socialist Germany researched areas that supported National Socialist ideology. Others just happened to live and work there. To a certain extent, then, Cornwell distances himself from the Hitler leadership myth and acknowledges the existence of a "polycratic" regime run by competing Nazi institutions such as the army or civil service.

Cornwell, an author and journalist, is known for his best-selling book Hitler's Pope, which is based on archival research. But he admits that Hitler's Scientists is not based on original material. Instead, he has drawn together a history of German science in the first half of the twentieth century, concentrating on the Third Reich from a wide reading of secondary sources.

The time is ripe for this book. Over the past 30 years, historians have unearthed new material and provided fresh interpretations on topics such as Fritz Haber — chemical warfare pioneer, Nobel prizewinner and Jew - racial hygiene, medicine, physics, the German atomic bomb, rocket science and the leading German scientific institution, the

Kaiser Wilhelm Society. But this is the first book to pull these themes together. Cornwell has written an engaging synthesis of the original research: articulate and intelligent, with an eye for telling detail or anecdote. His lively account is also a damning indictment: many scientists come across as depraved, amoral nerds who were willing to serve any regime if they got paid for it. Cornwell unearthed a quotation from Wernher von Braun, designer of the German V-2 'flying bomb' who went on to direct NASA's Apollo programme, illustrating that "he did not care if he worked for Uncle Joe or Uncle Sam: 'All I really wanted was an uncle who was rich'."

Even though much of the book relies on previous work, Cornwell puts his own stamp on the literature and sometimes tells the story better than the specialists. There are also some refreshing new slants: most of the recent academic literature ignores decisively important areas for the war effort such as radar, submarines and codes. Despite his familiarity with the recent literature, which usually provides a more nuanced account of science in the Third Reich than the contemporaneous reports and early postwar histories, Cornwell sometimes reverts back to the tone and interpretation of those earlier accounts. 